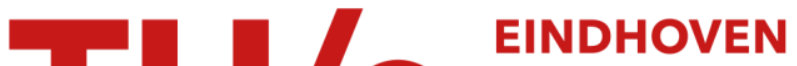 \\ UNIVERSITY OF \\ TECHNOLOGY
}

\section{The shape factor of conduction in a multiple channel slab and the effect of non-uniform temperatures}

\section{Citation for published version (APA):}

Ganzevles, F. L. A., \& Geld, van der, C. W. M. (1997). The shape factor of conduction in a multiple channel slab and the effect of non-uniform temperatures. International Journal of Heat and Mass Transfer, 40(10), 2493-2498. https://doi.org/10.1016/S0017-9310(96)00293-1

DOI:

10.1016/S0017-9310(96)00293-1

Document status and date:

Published: 01/01/1997

\section{Document Version:}

Publisher's PDF, also known as Version of Record (includes final page, issue and volume numbers)

\section{Please check the document version of this publication:}

- A submitted manuscript is the version of the article upon submission and before peer-review. There can be important differences between the submitted version and the official published version of record. People interested in the research are advised to contact the author for the final version of the publication, or visit the $\mathrm{DOI}$ to the publisher's website.

- The final author version and the galley proof are versions of the publication after peer review.

- The final published version features the final layout of the paper including the volume, issue and page numbers.

Link to publication

\section{General rights}

Copyright and moral rights for the publications made accessible in the public portal are retained by the authors and/or other copyright owners and it is a condition of accessing publications that users recognise and abide by the legal requirements associated with these rights.

- Users may download and print one copy of any publication from the public portal for the purpose of private study or research.

- You may not further distribute the material or use it for any profit-making activity or commercial gain

- You may freely distribute the URL identifying the publication in the public portal.

If the publication is distributed under the terms of Article 25fa of the Dutch Copyright Act, indicated by the "Taverne" license above, please follow below link for the End User Agreement:

www.tue.nl/taverne

Take down policy

If you believe that this document breaches copyright please contact us at:

openaccess@tue.nl

providing details and we will investigate your claim. 


\title{
The shape factor of conduction in a multiple channel slab and the effect of non-uniform temperatures
}

\author{
F. L. A. GANZEVLES and C. W. M. VAN DER GELD $\dagger$ \\ Eindhoven University of Technology, Faculty of Mechanical Engineering, P.O. Box 513, 5600 MB \\ Eindhoven, the Netherlands
}

(Received 26 March 1996 and in final form 8 July 1996)

\section{INTRODUCTION}

In a parallel plate compact heat exchanger made of a polymer the heat resistance of the plate is important of the performance for the heat exchanger [1,2]. This is because the heat conduction coefficient is relatively low, a typical value of $0.19 \mathrm{~W} \mathrm{~m}^{-1} \mathrm{~K}^{-1}$ for PolyVinylDiFluoride. The overall heat transfer generally depends on the shape of the polymer slab. Many studies were devoted to the quantification of the effect of the shape. Langmuir [3], Kutateladze [4], Sunderland and Johnson. [5], Lewis [6] and Hahne and Grigull [7] introduced shape factors to take this dependency in account. In this paper conduction of heat in the flow direction of the coolant is assumed to be negligible. Hahne and Grigull [7] summarize expressions for the shape factors of many two-dimensional (2D) geometries. However, only few shape factors seem to exist for a slab cooled from two sides containing multiple channels in a row. A typical cross-section of the geometry with multiple coolant channels as studied in this paper is schematzed in Fig. 1. Here $d_{1}$ denotes the length of the coolant channel in the direction of the gas flow and $d_{2}$ the length perpendicular to the gas flow direction. The coolant channels are centred at a distance $s$ from each other and the distance between each centre and the gas surface is $h$. The edges of the inner channels are not acute but slightly curved. Typical values of $d_{1}, d_{2}$ and $h$ are $1.37,1.47$ and 1.00 $\mathrm{mm}$, respectively [1].

In dropwise condensation a part of the surface of the condenser plate is dry and the remaining part is wetted. The overall heat transfer ratio can be measured but the heat resistance of the slab has to be computed. Van der Geld and Brouwers [2] use the relation of Kutateladze [4] for cylindrical channels, see equation (5), with $\pi R$ replaced by the half of the perimeter of one coolant channel, $\left(d_{1}+d_{2}\right) / 2$. In this paper it is investigated if the relation is valid for all radii and how the shape factor depends on $d_{1}$ and $d_{2}$. It is shown that for actual sizes of the PVDF heat exchanger plate the shape factor computed with Kutateladzes relation exceeds the actual shape factor by about $10 \%$.

$\dagger$ Author to whom correspondence should be addressed.

$\ddagger$ The heat resistance of the slab is now given by $R^{*}=h /\left(\lambda \cdot A_{1} \cdot F\right)=1 /(\lambda \cdot S)$ with $A_{1}=L \cdot W, L$ and $W$ the lengths of the plate in the direction of the coolant and gas, respectively. The total heat resistance $R_{\text {tot }}$ is $1 /\left(1 / R_{1}+1 / R_{0}+1 / R^{*}\right)$ with $R_{1}$ and $R_{0}$ the heat resistances by convection towards surfaces $A_{1}$ and $A_{0}$, respectively, i.e. $R_{1}=1 /\left(A_{1} \cdot h_{\text {conv }}\right)$ with $h_{\text {conv }}$ denoting the convective heat transfer coefficient, $\dot{Q}=\left(T_{1}-T_{0}\right) / R_{\text {tot }}$.
With dropwise condensation, the plate is partly wetted and the temperature at the gas side wall is not uniform since the condensation enthalpy is mainly released at the feet of the condensing drops. A typical wetted area fraction in dropwise condensation for air-stream mixtures is $36 \%$ [1]. This nonuniformity of the gas-sided temperature might affect the shape factor and bence the heat resistance of the condenser plate. This effect is therefore investigated in this paper.

\section{THEORY}

In the two-dimensional geometry of Fig. 1 the heat flux $q$, in $\mathrm{W} \mathrm{m}^{-2}$, is given by [8]

$$
q=\dot{Q} / A_{1}=\frac{\lambda}{A_{1}} \iint_{A_{1}} \frac{\partial T}{\partial n_{1}} \mathrm{~d} A_{1}
$$

if the heat flux is steady and the heat conduction coefficient $\lambda$ is independent of the temperature. Here $n_{1}$ is the outward normal of surface $A_{1}$. The shape factors, $\ddagger S$ and $F$, are defined as :

$$
\begin{aligned}
& S=\iint_{A_{1}} \frac{\partial T}{\partial n_{1}} \mathrm{~d} A_{1} /\left(T_{1}-T_{0}\right) \\
& \text { and } F=\frac{h}{A_{1}} \iint_{A_{1}} \frac{\partial T}{\partial n_{1}} \mathrm{~d} A_{1} /\left(T_{1}-T_{0}\right)
\end{aligned}
$$

and yields $\dot{Q}=\lambda \cdot S \cdot\left(T_{1}-T_{0}\right)$ and $q=\lambda \cdot F \cdot\left(T_{1}-T_{0}\right) / h$ with $T_{1}$ the average temperature of the PVDF plate at the gas side and $T_{0}$ that of the coolant side (see Fig. 2). $S$ represents the shape factor of Langmuir [3] as used by many others, e.g. Hahne and Grigull [7]. However, the factor $F$, apart from being dimensionless, has the following advantages:

(1) For a piece of slab that is not shaped in a special manner, i.e. which is flat, $F$ has the value 1.

(2) It has the straightforward interpretation of the ratio $h / \bar{h}$ with $h$ defined in Fig. 1 and $\bar{h}$ a 'conductive' mean thickness.

$S$ is used throughout this paper for ease of reference. Values of $F$ will be indicated at some places.

The Laplace equation for conduction with the present assumptions reads

$$
\frac{\partial^{2} \Theta}{\partial x^{2}}+\frac{\partial^{2} \Theta}{\partial y^{2}}=0
$$




\section{NOMENCLATURE}

\begin{tabular}{|c|c|c|c|}
\hline$A$ & surface $\left[\mathrm{m}^{2}\right]$ & $r$ & effective radius, $d_{1}^{(1-a)} \cdot d_{2}^{u}[\mathrm{~m}]$ \\
\hline$a, a_{0}, a_{1}$ & coefficients & $S$ & shape factor $[\mathrm{m}]$ \\
\hline & $\begin{array}{l}\text { length coolant channel in direction of the } \\
\text { gas flow [m] }\end{array}$ & $s$ & $\begin{array}{l}\text { distance between two successive cha } \\
\text { [m] }\end{array}$ \\
\hline$d_{2}$ & length coolant channel perpendicular to the & $T$ & temperature $[\mathrm{K}]$ \\
\hline$F$ & $\begin{array}{l}\text { gas flow direction }[\mathrm{m}] \\
\text { shape factor }\end{array}$ & $W$ & $\begin{array}{l}\text { length of heat exchanger plate in ga } \\
\text { direction }[\mathrm{m}]\end{array}$ \\
\hline$h$ & $\begin{array}{l}\text { distance between gas side surface and centre } \\
\text { coolant channel [m] }\end{array}$ & $\begin{array}{l}x \\
x^{*}\end{array}$ & $\begin{array}{l}\text { coordinate in gas flow direction }[\mathrm{m}] \\
x \text {-coordinate where the step occurs }\end{array}$ \\
\hline $\begin{array}{l}h_{\text {conv }} \\
L\end{array}$ & $\begin{array}{l}\text { heat transfer coefficient }\left[\mathrm{W} \mathrm{m}^{-2} \mathrm{~K}^{-1}\right] \\
\text { length of the heat exchanger plate in coolant } \\
\text { direction }[\mathrm{m}]\end{array}$ & $y$ & $\begin{array}{l}\text { coordinate perpendicular to the gas } \\
\text { direction }[\mathrm{m}] \text {. }\end{array}$ \\
\hline$\dot{Q}$ & heat flow rate $[\mathrm{W}]$ & \multicolumn{2}{|c|}{ Greek symbols } \\
\hline & heat flux $\left[\mathrm{W} \mathrm{m}^{-2}\right]$ & $\lambda$ & thermal conductivity $\left[\mathrm{W} \mathrm{m}^{-1} \mathrm{~K}^{-1}\right]$ \\
\hline$R$ & radius $[\mathrm{m}]$ & $\Theta$ & dimensionless temperature \\
\hline$R^{*}$ & heat resistance $\left[\mathrm{K} \mathrm{W}^{-1}\right]$ & & $\left(T-T_{0}\right) /\left(T_{1}-T_{0}\right)$ \\
\hline
\end{tabular}

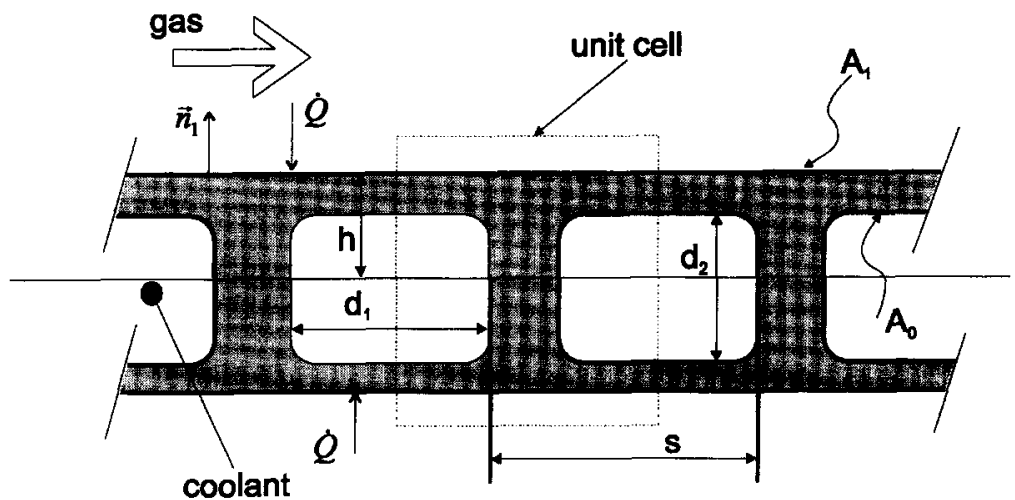

Fig. 1. Schematic of cross-section of finite slab with coolant channels.

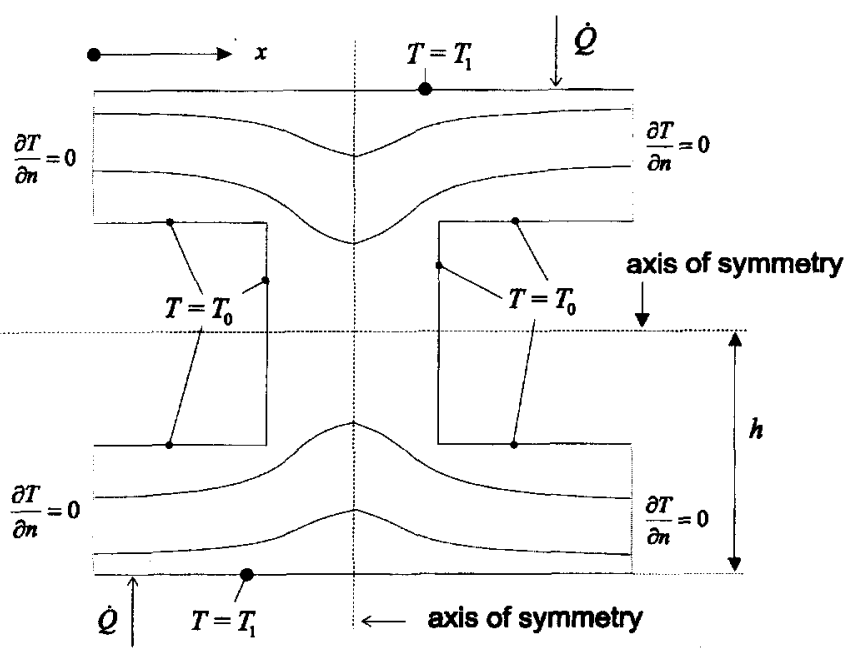

Fig. 2. Boundary conditions of a single cell of Fig. 1 with isothermals schematized. 
with dimensionless ternperature $\Theta=\left(T-T_{0}\right) /\left(T_{1}-T_{0}\right)$. The heat flux and the shape factor have been found by numerically solving the differential equation (3) for constant temperatures $T_{1}$ and $T_{0}$ at the gas and coolant side, respectively. Discretisation using the Crank-Nicholson method yields

$$
\begin{aligned}
& \left.\frac{\partial^{2} \Theta}{\partial x^{2}}\right|_{\mathrm{m}, \mathrm{n}}=\frac{\Theta_{\mathrm{m}+1, \mathrm{n}}+\Theta_{\mathrm{m}-1, \mathrm{n}}-2 \Theta_{\mathrm{m}, \mathrm{n}}}{(\Delta x)^{2}} \\
& \quad \text { and }\left.\frac{\partial^{2} \Theta}{\partial y^{2}}\right|_{\mathrm{m}, \mathrm{n}}=\frac{\Theta_{\mathrm{m}, \mathrm{n}+1}+\Theta_{\mathrm{m}-1, \mathrm{n}}-2 \Theta_{\mathrm{m}, \mathrm{n}}}{(\Delta y)^{2}} .
\end{aligned}
$$

The central node $\Theta_{m, n}$ of each Crank-Nicholson cell $[8,9]$ is estimated according to

$$
\begin{aligned}
\Theta_{\mathrm{m}, \mathrm{n}}=\frac{1}{2}(\Delta y)^{2}\left(\frac{\Theta_{\mathrm{m}+\mathrm{l}, \mathrm{n}}+\Theta_{\mathrm{m}-\mathrm{l}, \mathrm{n}}}{(\Delta x)^{2}+(\Delta y)^{2}}\right) & \\
+ & +\frac{1}{2}(\Delta x)^{2}\left(\frac{\Theta_{\mathrm{m}, \mathrm{n}+1}+\Theta_{\mathrm{m}, \mathrm{n}-1}}{(\Delta x)^{2}+(\Delta y)^{2}}\right)
\end{aligned}
$$

for step sizes $\Delta x$ and $\Delta y$ in $x$ and $y$ direction, respectively.

Because of symmetry only one cell of Fig. 1 has to be computed. The temperatures at $A_{1}$ and $A_{0}$ are known (see Figs. 1 and 2) and the gradients $\partial T / \partial n=\mathbf{n} \cdot \nabla T$ at the other boundaries are zero. All temperatures except that of the boundaries are set to zero as a first guess. New temperatures at the nodes are now calculated with equation (4). The process is reiterated until a steady state has been achieved. Convergence is said to be reached if the relative difference between successive calculated values, $\left(T_{\mathrm{n}, \mathrm{m}}^{j}-T_{\mathrm{n}, \mathrm{m}}^{j-1}\right) / T_{\mathrm{n}, \mathrm{m}}^{j}$, is less than $10^{-5}$. For sinall $d_{1}\left(d_{1}<3.6 \times 10^{-4} \mathrm{~m}\right)$ the number of iterations necessary is about 200 and for larger $d_{1}$ this is about 750 . The distance between the nodes of adjacent cells is $4 \times 10^{-5} \mathrm{~m}$ in both $x$ and $y$ directions. Increasing the number of nodes did not affect the value of $F$.

Alternatively, temperatures are computed for the same boundary conditions with the aid of the finite element package FIDAP ${ }^{\mathrm{TM}}$, version 7.52

\section{CYLINDRICAL CHANNELS}

For a row of cylindrical channels in a semi-infinite slab, as shown in Fig. 1, Kutateladze [4] gives the shape factor

$$
S_{\mathrm{cyl}}=\left(\frac{A_{1}}{s}\right) \cdot \pi / \ln \left(\frac{s}{\pi R} \sinh \left(\frac{\pi h}{s}\right)\right)
$$

with $R$ the radius of the cylinder, $s$ the distance between two successive cylinders, $h$ the distance between the centre of the cylinder and the surface and $A_{1}=2 \cdot s \cdot L, L$ being the length of the plate in the direction of the coolant. By selecting $A_{1}$ in this way, $\dot{Q}_{\mathrm{cyl}}=\lambda \cdot S$ ' $\left(T_{1}-T_{0}\right)$ obviously is the heat flow rate to both sides of a piece of slab with length $s$ : thus, $\dot{Q}=\frac{1}{2} \dot{Q}_{\text {cyl }}$. In Fig. 3 the dashed line represents relation (5). For six radii the shape factor has been computed with the finite element package FIDAP ${ }^{\mathrm{TM}}$ for $s=2 \mathrm{~mm}$ as indicated by FEM in Fig. 3. For small raclii there is fair agreement but for larger radii Kutateladze's relation yields too high values for $S_{\text {cyl, }}$, see Fig. 3. So equation (5) only holds for $R / s<0.30$.

To get a shape factor for the range $[0.30 ; 0.44]$ of $R / s$ the relation (5) is adapted. In the numerator a constant $a_{0}$ is added and in the deriominator a constant $a_{1}$ :

$$
S_{\mathrm{cyl}}=\left(\frac{A}{s}\right) \cdot a_{0} \pi / \ln \left(\frac{s}{a_{1} \pi R} \sinh \left(\frac{\pi h}{s}\right)\right) .
$$

$\dagger$ Conformal mapping $[4,10]$ is another method to determine the shape factor. However, the geometry of Fig. 1 is too complex to estimate the shape factor of this geometry by conformal mapping.
The fitted coefficients are $a_{0}=0.76 \pm 0.08$ and $a_{1}=1.26 \pm 0.05$. These values are given with a $95 \%$ confidence interval [11].

\section{RECTANGULAR CHANNELS}

To obtain an expression for the shape factor for the bundle of rounded rectangular channels of Fig. 1 the Kutateladze's relation is adapted once more. As opposed to equation (6) the radius $R$ is replaced by an effective radius $r=d_{1}^{(1-a)} \cdot d_{2}^{a}$. This yields

$S=\left(\frac{A_{1}}{s}\right) \cdot a_{0} \pi / \ln \left(\frac{s}{a_{1} \pi r} \sinh \left(\frac{\pi h}{s}\right)\right)$ and $F=\left(\frac{h}{A_{1}}\right) \cdot S$.

Note that $A_{\mathrm{t}} / s=2 \cdot L$, as before.

The shape factor has been computed both with the difference scheme (see Fig. 4) described above and with the finite element package FIDAP ${ }^{\mathrm{TM}}$, using the grids depicted in Fig. 4. The results of the Crank-Nicholson method and the FID$\mathrm{AP}^{\mathrm{TM}}$ runs agree within $0.5 \%$. The coefficients of equation (7) have been fitted to the computational results given in Fig. 5, yielding $a_{0}=0.67 \pm 0.02, a_{1}=0.728 \pm 0.006$ and $a=0.86 \pm 0.02$ for uniform temperatures at the boundary.

The value 0.86 for $a$ can be compared with the corresponding value 0.75 for a single rectangular cell in an infinite slab. In this case the shape factor is given by [4]

$$
S=5.7+\frac{d_{1}}{2 d_{2}} / \ln \left(\frac{3.5 h}{d_{1}^{0.25} \cdot d_{2}^{0.75}}\right)
$$

in which $h, d_{1}$ and $d_{2}$ have the same meaning as in equation (7) and Fig. 1. The effective radius, $r$, is dominated by $d_{2}$ since when the wall thickness, $\left(h-d_{2}\right)$, goes to zero the heat resistance goes to that of a thin plate, $R_{\mathrm{pl}}=\left(h-d_{2}\right) / \lambda$.

The shape factor for channels with the geometry of Fig. 1 is about $5 \%$ smaller than that of exactly rectangular channels. In this case computations with finite difference scheme and with FIDAP ${ }^{\mathrm{TM}}$ have yielded $a_{0}=0.70 \pm 0.02$, $a_{1}=0.730 \pm 0.005$ and $a=0.88 \pm 0.02$, to be used in equation (7)

In practical applications the slab is cooled by water flowing through the channels and heated by gas condensing at the gas-sided surface $A_{1}$, see the introduction and [2]. Underneath condensing drops the plate temperature is higher then elsewhere [2]. To simulate this, the temperature is given a Heaviside step function of distance $x$, see Fig. 2. The step occurs at $x=x^{*}$, i.e. in $\left[0 ; x^{*} / s\right]$, the temperature is taken to be $1.05 \cdot T_{1}$ and in $\left\langle x^{*} / s ; 1\right]$ it is $T_{1}$. The average wall

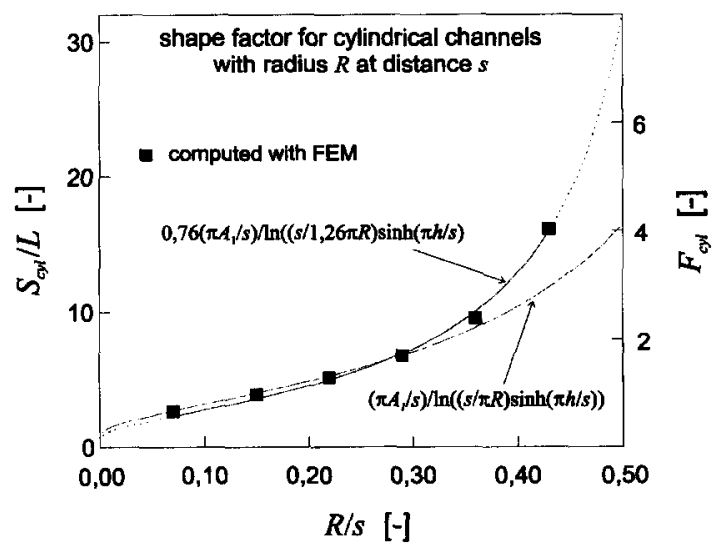

Fig. 3. Computations of the shape factor for a row of cylindrical channels in an infinite slab. 


\section{difference method}

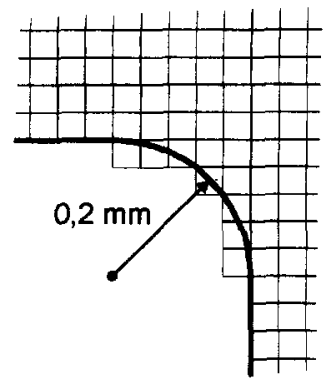

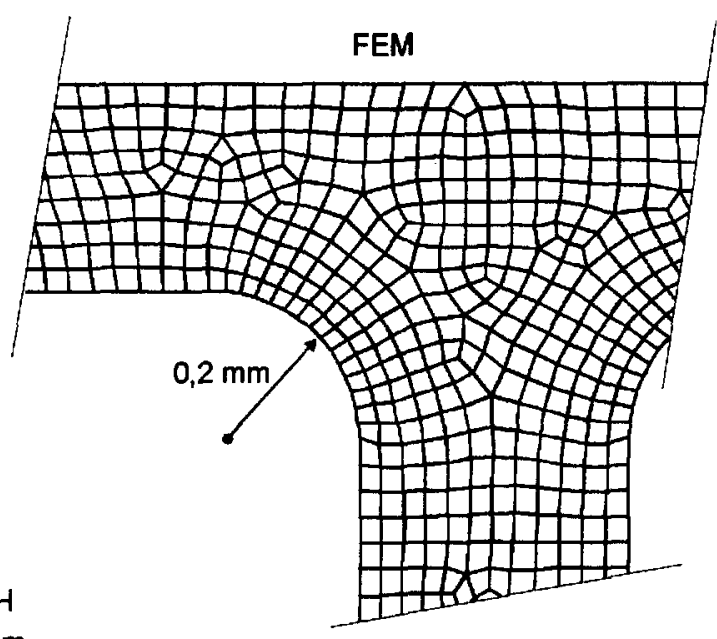

$0,1 \mathrm{~mm}$

Fig. 4. Nodes used to model the rounded corner in the difference method and finite element method.

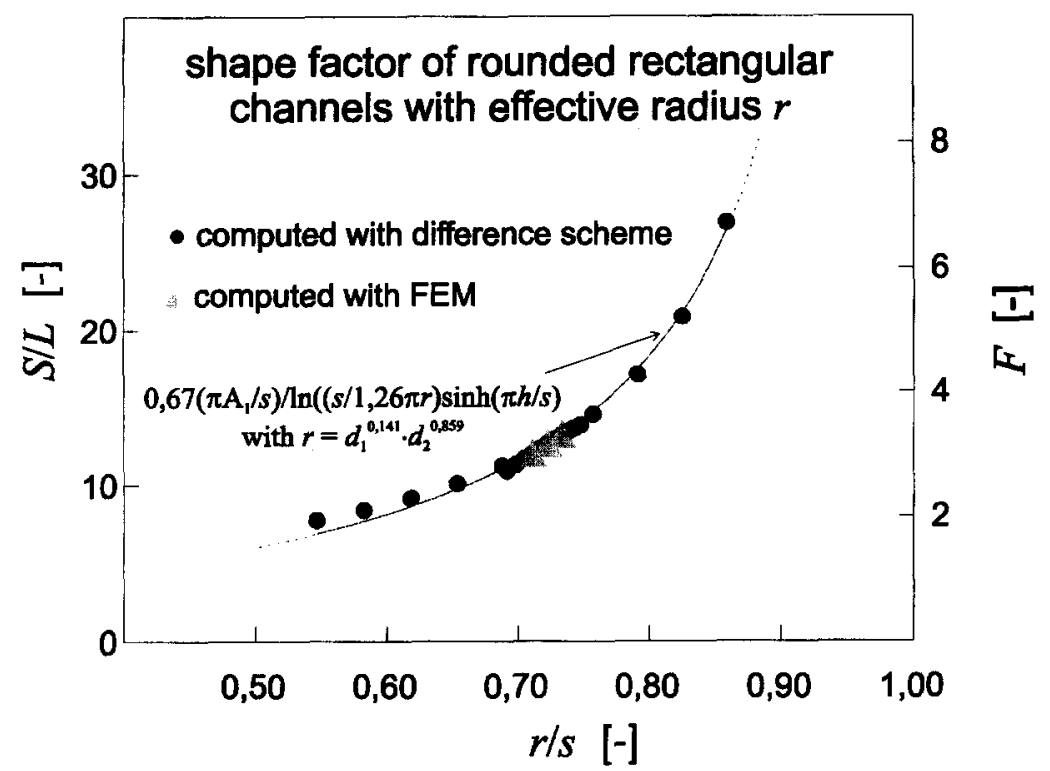

Fig. 5. Shape factor of the rounded rectangular channels of the geometry of Fig. 1.

temperature is $\bar{T}_{1}=\left(1+0.05 \cdot x^{*} / s\right) \cdot T_{1}$ and replaces $T_{1}$ in equation (2) and related equations. The resulting shape factor is named $S_{\mathrm{x}^{*} / \mathrm{s}}$. With uniform temperature, it is given by $S_{0}=S_{0 / \mathrm{s}}$. Computations are performed with FIDAP ${ }^{\mathrm{TM}}$ for 10 different $x^{*} / s$ values. The number of nodes in the grid is 2038 and each element has four nodes (quadrilateral elements). Further refining the grid changed the outcome by $0,1 \%$, typically. Figure 6 summarizes the results for $\mathrm{DEV}=100 \% \cdot\left(S_{\mathrm{x}^{*} / 5}-S_{0}\right) / S_{0}$. At places where $T_{1}<T_{1}$, the dimensionless temperature $\Theta$ exceeds 1 . The non-uniformity of the temperature does not significantly affect the shape factor and the heat resistance of the condenser plate. For wetted area fractions of about $36 \%$ that are typical in dropwise condensation of air-steam mixtures [1] the deviation of the shape factor is about $0.3 \%$. In Fig. 7 the computed isotherms are plotted for the case $x^{*} / s=0.35$.

\section{CONCLUSIONS}

For the geometry of Fig. 1 the shape factor $S$, defined by equation (2), is given by equation (7) with $a_{0}=0.67 \pm 0.02$, $a_{1}=0.728+0.006$ and $a=0.86+0.02$. It holds for $0.60 \leqslant r / s \leqslant 0.83$, with $r$ the effective radius given by $d_{1}^{0.14}$. $d_{2}^{0,86}$. For exactly rectangular channels equation (7) can also be used, with coefficients $a_{0}=0.70 \pm 0.02, a_{1}=0.730 \pm 0.005$ and $a=0.88 \pm 0.02$. It holds for $r / s<0.85$. The shape factor of Kutateladze (5) for cylindrical channels is only valid for radii smaller than $30 \%$ of $s$. For larger radii the modified relation (6) can be used with $a_{0}=0.76 \pm 0.08$ and $a_{1}=1.26 \pm 0.05$.

If the gas-sided wall temperature is not uniform but follows a prescribed step function, the shape factor differs only by $0.3 \%$ if the average wall temperature is used. 


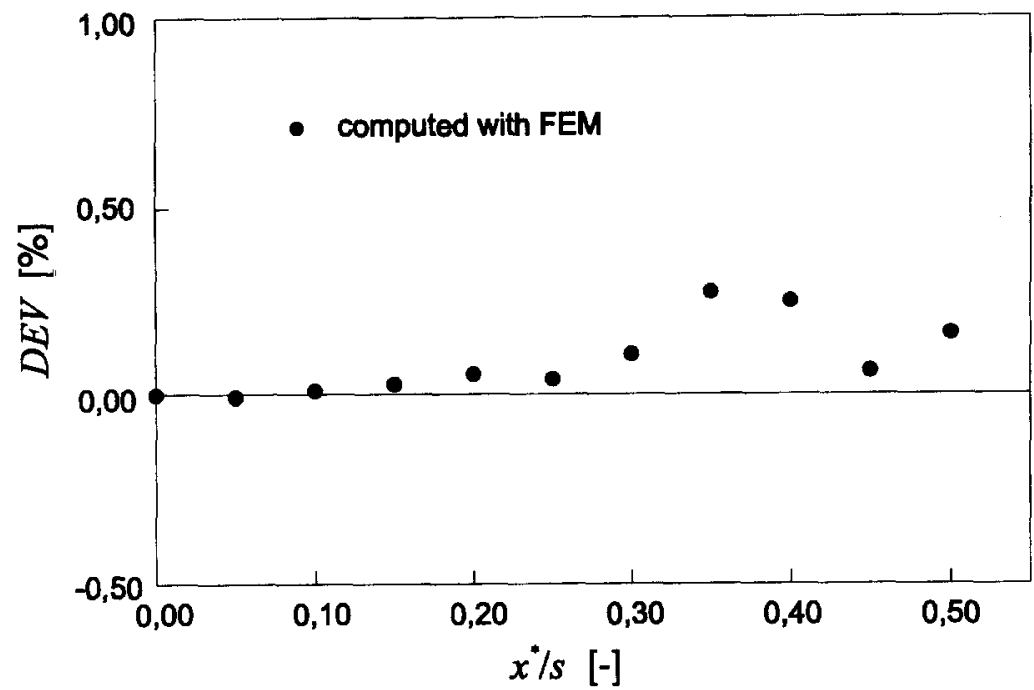

Fig. 6. Percentage of relative increase in shape factor of rounded rectangular channels if in $\left[0 ; x^{*} / s\right]$ the temperature at the gas-sided surface is increased to $1.05 \cdot T_{1}$.

Temperature contour plot

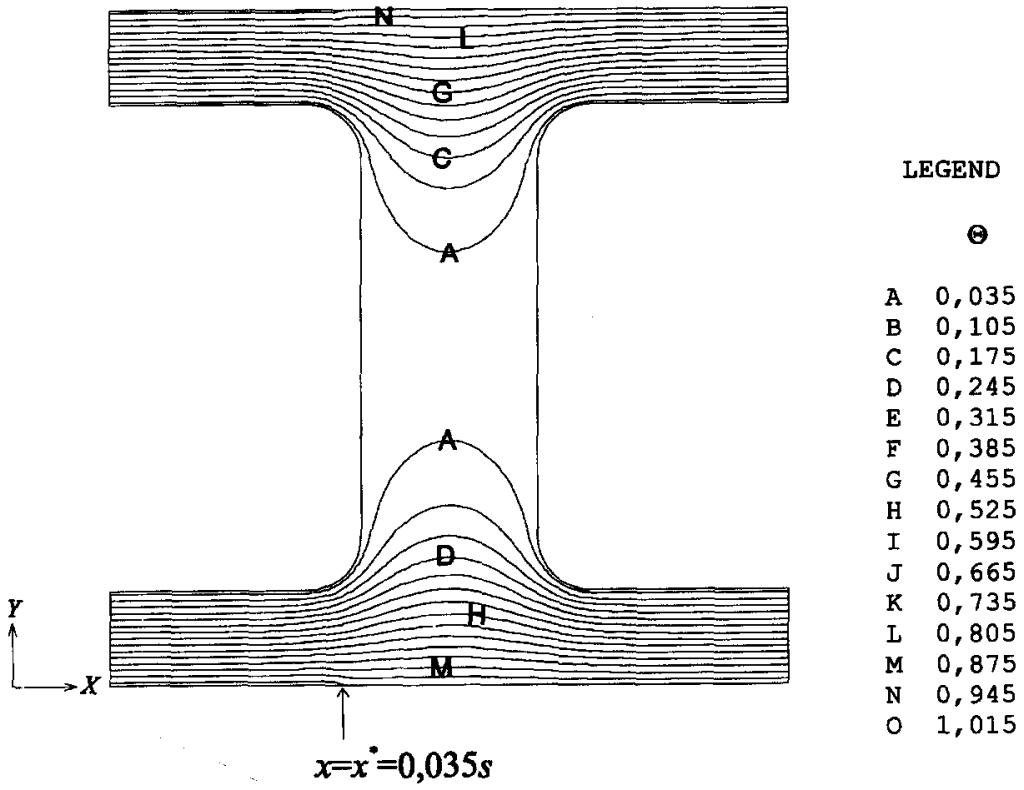

Fig. 7. Computation of isothermals for $x^{*} / s=0.35$ with FIDAP ${ }^{\mathrm{TM}}$.

Throughout this paper the classical definition of the shape factor, $S$, has been used. However, the authors believe that the shape factor $F$ as defined in equation (2) is more useful for reasons given below equation (2).

\section{REFERENCES}

1. F. L. A. Ganzevles and C. W. M. van der Geld, In situ measurements of wetting rate and local temperatures with dropwise condensation in a compact heat exchanger. Proceedings of the 30th National Heat Conference, HTD-314 Vol. 12, pp. 68-76. ASME, New York (1995).
2. C. W. M. van der Geld and H. J. H. Brouwers, The mean condensate heat resistance of dropwise condensation with flowing, inert gases, Heat Mass Transfer 30, 435-445 (1995).

3. I. Langmuir, E. Q. Adams and G. S. Meikle. Flow of heat thru furnace walls: the shape factor, Trans. Am Electrochem. Soc. 24, 53-84 (1913).

4. S. S. Kutateladze, Fundamentals of Heat Transfer (1st Edn), p. 93. Edward Arnold, London (1963).

5. J. E. Sunderland and K. R. Johnson, Shape factors for heat conduction through bodies with isothermal or convective boundary conditions. ASHRAE Trans. 80, 237241 (1964).

6. G. K. Lewis, Shape factors in conduction heat flow for 
circular bars and slabs with various internal geometries, Int. J. Heat Mass Transfer 11, 985-992 (1967).

7. E. Hahne and U. Grigull, Formfaktor und Formwiderstand der stationären mehrdimensionalen Wärmeleitung (in German), Int. J. Heat Mass Transfer 18, 751-767 (1975).

8. V. D. I., V.D.I.-Wärmeatlas (in German, 6. Auflage) p. Ea 4. V.D.I. Verlag GmbH, Düsseldorf (1991).

9. P. J. Davis and I. Polonsky, Numerical interpolation, differentiation and integration. In Handbook of Math ematical Functions (Edited by M. Abramowitz and I. A Stegun), Chap. 25, Dover, New York (1972)

10. H. S. Carslaw and J. C. Jaeger, Conduction of Heat in Solids (2nd Edn), pp. 441-454. Clarendon Press, Oxford (1986).

11. S. J. Kline and F. A. McClintock, Describing uncertainties in single-sample experiments, Mech. Engng 75 , 3-8 (1953). 